\title{
The Valuation of Organizational Capital
}

\author{
Fiala Roman, Borrivková Jana
}

\begin{abstract}
The authors' aim was to create a model suitable for measuring organization capital. This model was produced by means of the Forward and Backward Stepwise methods, on the basis of company information. Low p-levels (approaching 0) show the statistical significance of all regression coefficients, including the intercept. Organizational capital of 2,796 companies in the Czech Republic was quantified. A statistically significant correlation between organizational capital and return on equity (ROE), as well as between organizational capital and return on assets (ROA), has been established. This article is a part of the results of the project No. 402/09/2057 "Measurement and Management of Intangible Assets Impact on Firm Performance" financed by Czech Science Foundation.
\end{abstract}

Key words: organizational capital, linear regression model, performance, return on equity, return on assets, return on sales, correlation

\section{INTRODUCTION}

A number of authors share the view that firm organizational capital can, in a significant way, contribute to increasing firm productivity. However, there is no consensus definition of organizational capital, of the method of measuring it, or the best way to quantify its contribution to output (current or future). Unlike physical capital, its value does not appear on the balance sheet of a firm. As there is no market for organizational capital, which could be used for measuring its value, this paper focuses on establishing and describing relationships between variables available with a view to measuring organizational capital.

Baron and Armstrong (2007, p. 14) define organizational capital as embedded or institutionalized knowledge that may be retained with the belp of information technology on readily accessible and easily extended databases. It can include explicit knowledge that has been recorded on a database or in manuals and standard operating procedures, or tacit knowledge that has been captured, exchanged and, as far as possible, codified. Organizational capital is created by people (human capital) but it is also the outcome of social capital interactions.

Evenson and Westphal (1995) define organizational capital as the knowledge used to combine human skills and physical capital into systems for producing and delivering want-satisfying products.

Black and Lynch (2005) divide organizational capital into three broad components - workforce training, employee voice, and work design. Black and Lynch assume, for the sake of simplicity, that education decisions are primarily individual based and made independently from the employment relationship. But workplace training is a joint decision undertaken by the worker and the firm to invest in additional skills training after an employment relationship has begun. This workforce training, along with the education a worker brings to a job, raises the productive capacity of a firm. 
The second component of organizational capital, according to Black and Lynch (2005), is employee voice. By this they mean those organizational structures that give workers input into the decision-making associated with the design of the production process and greater autonomy. Examples of practices in this component include employee suggestion box in the lunch room, employees being consulted individually about their views, individual job enrichment schemes, employees being consulted in groups, self-managed teams where production employees work in a semi-autonomous setting.

The third component of organizational capital, according to Black and Lynch (2005), is work design, including the use of cross-functional processes that result in more flexible allocation and re-allocation of labour in the firm. This component of organizational capital includes practices like reengineering efforts that may involve changing the occupational structure of workplace, or benchmarking.

The possibilities of individual authors' approach to the measurement of organizational capital can be noted in research studies. The first approach is quantification of organizational capital using questionnaire survey among companies. This procedure was chosen for instance by Huselid (1995), Delaney and Huselid (1996), Becker and Huselid (1998), Youndt and Snell (2004), Black and Lynch (2005). The second approach is measurement of organizational capital by creating models. Organizational capital is measured in this way for instance by Atkeson and Kehoe (2002), Lev and Radhakrishnan (2003), (2004), Miyagawa and Kim (2008), Ludewig and Sadovski (2009), Fiala and Borůvková (2011a), (2011b).

Atkeson and Kehoe (2005) use for measurement of organizational capital U.S. national income and product accounts (NIPA). In the standard growth model, output is accounted for as payments to labour and to psychical capital. Using this growth model to analyze NIPA data on the U.S. manufacturing sector during 1959-1999, the authors find that nearly $9 \%$ of the output of this sector is not accounted for by payments to either of these factors. Cited authors interpret his unaccounted-for output as payments to various forms of unmeasured capital or monopoly rents. Atkeson and Kehoe (2005) find that $4 \%$ of output in the U.S. manufacturing sector can be accounted for as payments to organizational capital. Thus, a little less than half of the nearly $9 \%$ unaccounted-for output in manufacturing can be accounted for as payments to organizational capital.

Lev a Radhakrishnan (2003), (2004) use following function to estimate organizational capital:

$S A L E_{i t}=a_{0 i t} P P E_{i t}^{b_{1}} E M P_{i t}^{b_{2}} R N D_{i t}^{b_{3}} e_{i t}$,

where $\mathrm{SALE}_{\mathrm{it}}$ is the revenue of firm $i$ in year $t, \mathrm{a}_{0 \mathrm{it}}$ stands for organizational capital, $\mathrm{PPE}_{\mathrm{it}}$ is the net value of plant, property, and equipment, $\mathrm{EMP}_{\mathrm{it}}$ is the number of employees, $\mathrm{RND}_{\mathrm{it}}$ is the firm's research and development capital and $\mathrm{e}_{\mathrm{it}}$ is an error term. Coefficient of determination $\mathrm{R}^{2}$ for this model was calculated at values 0.625 .

Miyagawa and Kim (2008) found that organizational capital is associated with investment in research and development assets and marketing assets. The model of cited authors is based on the firm value approach. They include organizational capital as a production factor in the following production function: 
$Y_{i t}=F\left(B\left(K_{i t}^{I}, O_{i t}\right), K_{i t}^{T}, L_{i t}, M_{i t}, H_{i t}, \Theta_{i t}\right.$,

where $Y_{i t}$ is a gross output of firm $i$. In this equation, they assume two kinds of capital goods: one is complementary to organizational capital $\left(\mathrm{K}_{\mathrm{it}}\right)$ and the other is not $\left(\mathrm{K}^{\mathrm{T}}{ }_{\mathrm{it}}\right)$. $\mathrm{O}_{\mathrm{it}}$ is organizational capital, $\mathrm{L}_{\mathrm{it}}$ is labour input, $\mathrm{M}_{\mathrm{it}}$ is intermediate input, and $\Theta_{\mathrm{it}}$ shows the technology of firm $i . \mathrm{H}_{\mathrm{it}}$ represents investment in organizational capital.

Ludewig and Sadovski (2009) use linear regression model of Lev and Radhakrishnan (2003) and measure with the help of Cobb-Douglas production function, which they amend with a term for organizational capital $(\Omega)$ :

$Q_{i, t}=A \Omega_{i t}^{\beta_{1}} K_{i, t}^{\beta_{2}} L_{i, t}^{\beta_{3}}$,

where $\mathrm{Q}$ denotes the output, $\mathrm{K}$ the capital stock and $\mathrm{L}$ the labour input of establishment $i$ in period $t$. The constant A represents overall efficiency. Their results indicate that organizational capital has a substantial impact on performance.

Fiala and Borůvková (2011a) designed a model of firms' sales, as a function of their tangible fixed assets, intangible assets, and staff costs, which they used to measure firm organizational capital. Organizational capital of 2796 companies in the Czech Republic was quantified and its correlation with return on equity index, return on sales index, and return on assets index was calculated. A statistically important linear correlation between organizational capital and return on assets (ROA), as well as between organizational capital and return on equity (ROE), has been established.

Fiala and Borůvková (2011b) created three linear regression models for the years 2006, 2007 and 2008 of roughly 270 companies based in the Vysocina region were produced by means of the Forward and Backward Stepwise methods, on the basis of company information.

The impact of organizational capital on firm productivity was studied, among others, by Huselid (1995), Delaney and Huselid (1996), Ichniowski, Shaw and Prennushi (1997), Ichniowski and Shaw (1999), Youndt and Snell (2004).

Huselid (1995) indicated that organizational capital has statistically significant impact on shortand long-term measures of corporate financial performance. In a similar research, Delaney and Huselid (1996) found a positive association between human resource management practices and firm performance measures. Ichniowski, Shaw and Prennushi (1997) found support for the conclusion that groups or clusters of complementary human resource management practices have large effects on productivity, while changes in individual work practices have little or no effect on productivity. A similar conclusion was reached by Ichniowski and Shaw (1999) in a subsequent study. They found that the set of lines having innovative human resource practices, in Japan and in the USA, are on average seven percent more productive than the U.S. lines employing traditional human resource practices.

The aim of this article is to create a model suitable for measuring organization capital, that is to say a model with relative high coefficient of determination, in which coefficients of all regressors and the intercept are statistically significant. 
The next aim is to verify following three hypotheses:

- $\mathrm{H}_{1}$ : An organization's level of organizational capital is positively related to return on equity (ROE).

- $\mathrm{H}_{2}$ : An organization's level of organizational capital is positively related to return on assets (ROA).

- $\mathrm{H}_{3}$ : An organization's level of organizational capital is positively related to return on sales (ROS).

\section{MATERIAL AND METHODS}

The analysis was based on data obtained from Creditinfo database, a major part of Albertina Data database. Creditinfo database ranks among the most complete sources of firms' data in the Czech Republic. The database includes individual firms' economic data based on their annual reports. This represents approximately 250 pieces of data per year per firm. Apart from basic information on commercial name, registered address, and firm's identification number the data also includes business activity, number of employees, legal form, and type of ownership. Information on turnover is available in respect of about 900000 firms.

Records relevant to the year 2008 concerning companies with more than 20 employees, having their registered address in the Czech Republic, were selected. The number of firms totalled 5 468, out of which only 2796 were selected for the analysis. Firms that had not supplied complete data on all variables required for the analysis were not included in the analysis.

For the purpose of the analysis, a linear regression model was developed initially, encompassing two independent variables: tangible fixed assets (TFA) and staff costs (SC). Sales represent a dependent variable.

According to Synek (2007), tangible fixed assets are used by a firm for a longer period of time and gradually depreciate in value (e.g. constructions, machinery, buildings, manufacturing equipment, means of transport), or are used without depreciation (e.g. plots of land, works of art).

Staff costs include wages, social security and health insurance contributions, bonuses paid to members of the board of a company or cooperative enterprise, and state benefits. For the purpose of this paper, sales include revenues from sales of goods and services. Table 1 shows descriptive statistics (sample size, mean, median, minimum, maximum, standard deviation) denoting chosen variables.

Tab. 1 - Descriptive Statistics. Source: own calculation.

\begin{tabular}{|l|c|c|c|c|c|c|}
\cline { 2 - 7 } \multicolumn{1}{c|}{} & $\mathrm{N}$ & Mean & Median & Minimum & Maximum & Std. Dev. \\
\hline $\begin{array}{l}\text { Tangible assets } \\
\text { (CZK thousand) }\end{array}$ & 2796 & 98076.1 & 17070 & -11666 & 46364990 & 1019300 \\
\hline $\begin{array}{l}\text { Staff costs } \\
\text { (CZK thousand) }\end{array}$ & 2796 & 30271.6 & 18354 & 187 & 2324216 & 58816 \\
\hline $\begin{array}{l}\text { Sales } \\
\text { (CZK thousand) }\end{array}$ & 2796 & 231395.9 & 99116,5 & 47 & 13305658 & 568069 \\
\hline
\end{tabular}


The authors of this paper attempted to use models described in literature so far - Lev and Radhakrishnan (2003), (2004). However, the data available proved unsuitable for multiplicative models as it did not give statistically significant coefficients. For modelling sales, the authors therefore used multiple linear regression (stepwise method).

Linear regression attempts to model the relationship between variables by fitting a linear equation to observed data. Variables $X_{1}, X_{2}$ are considered to be explanatory (independent) variables, and the other $(Y)$ is considered to be a dependent variable. A linear regression line has an equation of the form $y=b_{0}+b_{1} x_{1}+b_{2} x_{2}$. The model design therefore tries to answer the question: How are sales (dependent variable $Y$ ) impacted by: (Fiala, Borůvková, 2011c)

- tangible fixed assets (independent variable $X_{1}$ ),

- staff costs (independent variable $X_{2}$ )?

If, prior to analysis, we standardize all variables, we can determine a relative contribution of the predictor $X_{\mathrm{j}}$ to prediction of the variable $Y$ from standardized regression coefficients $\beta_{\mathrm{j}}$.

Linear relationships between independent variables and a dependent variable are prerequisite for a correct linear model design. Individual predictors, on the other hand, should be correlated as little as possible.

The coefficient of determination $\mathrm{R}^{2}$, which is the ratio of the modeled variability to the overall variability, equals the part of variability of the variable sales, explained by the predictors of TFA and $S C$.

This design of linear regression model was further used for estimation of a firm-specific intercept. The authors of this paper assumed, drawing from ideas and calculations presented by Lev and Radhakrishnan (2004), that the intercept value corresponds with firm organizational capital.

As a next step, Spearman rank correlation coefficients were calculated between the derived intercept value (firm organizational capital) and return on sales (ROS), and between return on assets (ROA) and return on equity (ROE), which measure correlation between the variables. Profit before tax was used when calculating profitability indicators, to eliminate effects of tax optimization.

Program Statistica was used for all analyses.

\section{RESULTS AND DISCUSSION}

Table 2 shows Spearman rank correlation coefficients between variables TFA, SC, and sales. Highlighted values (bold letters) are statistically significant at $p$-level 0.05 . 
Tab. 2 - Spearman correlation coefficients. Source: own calculation.

\begin{tabular}{|l|c|c|c|}
\cline { 2 - 4 } \multicolumn{1}{c|}{} & $\begin{array}{c}\text { Tangible fixed assets } \\
\text { (CZK thousand) }\end{array}$ & $\begin{array}{c}\text { Staff costs } \\
\text { (CZK thousand })\end{array}$ & $\begin{array}{c}\text { Sales } \\
\text { (CZK thousand) }\end{array}$ \\
\hline $\begin{array}{l}\text { Tangible fixed assets } \\
\text { (CZK thousand) }\end{array}$ & 1.000000 & $\mathbf{0 . 4 5 8 8 3 1}$ & $\mathbf{0 . 4 6 0 6 0 4}$ \\
\hline $\begin{array}{l}\text { Staff costs } \\
\text { (CZK thousand) }\end{array}$ & $\mathbf{0 . 4 5 8 8 3 1}$ & 1.000000 & $\mathbf{0 . 7 0 2 1 1 6}$ \\
\hline $\begin{array}{l}\text { Sales } \\
\text { (CZK thousand) }\end{array}$ & $\mathbf{0 . 4 6 0 6 0 4}$ & $\mathbf{0 . 7 0 2 1 1 6}$ & 1.000000 \\
\hline
\end{tabular}

It is desirable for correlations between the independent variables TFA and $S C$ to be statistically insignificant, or at least low. Furthermore, it is desirable for correlation coefficients between the dependent variable and every independent variable to be high and statistically significant. Table 2 shows that this condition was not met fully - correlation between the independent variables $S C$ and TFA is significant, but only moderate.

The linear regression model design includes all the independent variables; low $p$-levels furthermore indicate that all regression coefficients, as well as the intercept, are statistically significant. It was therefore established, at $0.05 p$-level, that all two independent variables, as well as the intercept, impact the dependent variable sales.

Table 3 shows regression coefficients values, therefore regression equation for sales is:

SALES=97696+0.25TFA+3.62 SC,

where TFA represents tangible fixed assets, and $S C$ represents staff costs.

Coefficients in the model are very easy to interpret: a change in TFA by one unit results in an increase in sales by 0.25 units, and a change in $S C$ by one unit results in an increase in sales by 3.62 units.

Tab. 3 - Linear regression model. Source: own calculation.

\begin{tabular}{|l|c|c|c|c|c|}
\cline { 2 - 6 } \multicolumn{1}{c|}{} & Param. & Std. Err. & $\mathrm{t}$ & $\mathrm{p}$ & Beta (B) \\
\hline Intercept & 97696.22 & 9600.149 & 10.17653 & 0.000000 & \\
\hline $\begin{array}{l}\text { Tangible fixed } \\
\text { assets } \\
\text { (CZK thousand) }\end{array}$ & 0.25 & 0.008 & 29.20274 & 0.000000 & 0.441049 \\
\hline $\begin{array}{l}\text { Staff costs } \\
\text { (CZK thousand) }\end{array}$ & 3.62 & 0.146 & 24.81843 & 0.000000 & 0.374833 \\
\hline
\end{tabular}

Coefficients $\beta$ shown in table 3 serve to evaluate relative contribution of predictors. These coefficients were calculated by standardizing data prior designing the model. Values of coefficients $\beta$ clearly indicate that the dependent variable sales is impacted the most by the variable $S C$. The dependent variable sales depends on TFA, and $S C$ but also on the intercept, which the authors believe to equate with the value of firm organizational capital. 
Correlation between firm productivity and organizational capital is confirmed by number of studies, e.g.: Huselid (1995), Delaney and Huselid (1996), Ichniowski, Shaw and Prennushi (1997), Youndt and Snell (2004). The authors therefore conclude that the designed model can be used for calculation of firm-specific organizational capital, provided firm-specific values of all independent variables (TFA, SC), as well as the value of the dependent variable sales, are known.

A statistically significant coefficient of determination $R^{2}$ was consequently calculated at values higher than 0.37 which leads to the conclusion that the model design explains more than $37 \%$ of variability of the dependent variable.

The fitting of the model is also shown using the F-statistics and its p-level $(p=0.00)$. In this case a statistically significant value has been arrived at, also indicating the fitting of the model.

The described linear regression model was used for estimation of the intercept for all firms. The intercept for each firm was calculated, using the regression equation, from the firm-specific values of all independent variables (TFA, SC), and the dependent variable (sales). Table 4 shows characteristics denoting the intercepts calculated.

Tab. 4 - Descriptive statistics. Source: own calculation.

\begin{tabular}{|c|c|c|c|c|c|c|}
\cline { 2 - 7 } \multicolumn{1}{c|}{} & $\mathrm{N}$ & Mean & Median & Minimum & Maximum & Std. Dev. \\
\hline Intercept & 2796 & 97293.81 & 16120.88 & -5182718 & 12687188 & 450884.1 \\
\hline
\end{tabular}

Finally, a linear dependence between the intercepts calculated (which are assumed to correspond with firm organizational capital) and three profitability indicators return on sales, return on assets and return on equity was studied and described. For this purpose, Spearman correlation coefficients were calculated, as shown in table 5. Highlighted values (bold letters) are statistically significant at $p$-level 0.05 .

Tab. 5 - Spearman correlation coefficients. Source: own calculation.

\begin{tabular}{|l|c|c|c|c|}
\cline { 2 - 5 } \multicolumn{1}{c|}{} & $\begin{array}{c}\text { Organizational } \\
\text { capital }\end{array}$ & ROE & ROA & ROS \\
\hline Organ. capital & 1.000000 & $\mathbf{0 . 1 9 4 1 4 9}$ & $\mathbf{0 . 1 6 2 9 3 8}$ & 0.028103 \\
\hline ROE & $\mathbf{0 . 1 9 4 1 4 9}$ & 1,000000 & $\mathbf{0 , 7 1 6 3 8 3}$ & $\mathbf{0 , 5 9 0 5 7 4}$ \\
\hline ROA & $\mathbf{0 , 1 6 2 9 3 8}$ & $\mathbf{0 , 7 1 6 3 8 3}$ & 1,000000 & $\mathbf{0 , 9 0 0 7 7 8}$ \\
\hline ROS & 0.028103 & $\mathbf{0 , 5 9 0 5 7 4}$ & $\mathbf{0 , 9 0 0 7 7 8}$ & 1,000000 \\
\hline
\end{tabular}

A minor correlation has been established between organizational capital and return on equity as well as between organizational capital and return on assets, thus, hypotheses 1 and 2 are supported. A statistically significant linear relationship has not been established between organizational capital and return on sales (hypothesis 3). 


\section{CONCLUSION}

The authors designed the linear regression model for 2796 firms in the Czech Republic which encompasses two independent variables TFA a $S C$, and where all the regression coefficients including the intercept are statistically significant. On the level of significance of 0.05 was shown that all two independent variables, as well as the intercept, impact the dependent variable sales.

The regression equation for sales has been defined as follows:

SALES=97696+0.25TFA+3.62SC,

where TFA represents tangible fixed assets, and $S C$ represents staff costs. The model shows that a change in TFA by one unit results in an increase in sales by 0.16 units, and a change in SC by one unit results in an increase in sales by 3.73 units. The coefficient of determination $R^{2}$ is statistically significant, and was calculated at values higher than 0.37 which can lead to the conclusion that the designed model explains more than $37 \%$ of variability of the dependent variable. The coefficient of determination value is not high, however it is comparable with the values in some of the models published to date.

The dependent variable sales therefore depends on TFA, SC but also on the intercept, which the authors believe to equate with the value of firm organizational capital which assumption is supported by other studies. The authors have therefore concluded that the model design developed can be used for calculating firm organizational capital if the firm-specific values of all variables used in the model are available.

Finally, the calculated linear regression model was used for establishing the intercepts for all firms. A linear dependence between the intercepts calculated, which should correspond with firm organizational capital, and three profitability indicators return on sales, return on assets and return on equity was studied and described. For this purpose, Spearman correlation coefficients were calculated.

A statistically significant but weak linear dependence has been established between organizational capital and return on equity, as well as between organizational capital and return on assets, and thus the first and second hypotheses $\left(\mathrm{H}_{1}, \mathrm{H}_{2}\right)$ were confirmed. A correlation between organizational capital and return on sales has not been established and thus the third hypothesis $\left(\mathrm{H}_{3}\right)$ was not been confirmed.

\section{SUGGESTION FOR FURTHER RESEARCH}

The authors attribute this outcome mainly to a wide variety of firms included in the study. In their future paper the authors will describe a similar model designed specifically for firms in Vysocina region. Since the value of the coefficient of determination exceeds 0.93 and the correlation between organizational capital and profitability is strong (Fiala, Borůvková, 2011b), the authors propose to divide the 2796 firms included in this study into smaller groups, according to their size or General Industrial Classification of Economic Activities (NACE) and to design an individual model for each such group. 


\section{References}

1. Atkeson, A. \& Kehoe, P. J. (2002). Measuring Organization Capital. NBER Working Paper, 8722. Retrieved from http://citeseerx.ist.psu.edu/viewdoc/download?doi=10.1.1.159.7193\& rep=rep1\&type $=$ pdf

2. Baron, A. \& Armstrong, M. (2007). Human capital management: achieving added value through people. London: Kogan Page.

3. Becker, B. E. \& Huselid, M. A. (1998). High performance work systems and firm performance: a synthesis of research and managerial implications. Research in Personnel and Human Resources Management, 16, 53-101.

4. Black, S. E. \& Lynch, L. M. (2005). Measuring Organizational Capital in the New Economy. (2005). The Institute for the Study of Labor Discussion Paper, 1524. Retrieved from http://cosmic.rrz.uni-hamburg.de/webcat/hwwa/edok05/de2070t/dp1524.pdf

5. Delaney, J. T. \& Huselid, M. A. (1996). The Impact of Human Resource Management Practices on Perceptions of Organizational Performance. Academy of Management Journal, 39 (4), 949-969. http://dx.doi.org/10.2307/256718

6. Evenson, R. E. \& Westphal, L. E. (1995). Technological Change and Technological Strategy. In Handbook of Development Economics. Amsterdam: North Holland. http://dx.doi. org/10.1016/S1573-4471(05)80009-9

7. Fiala, R. \& Borůvková, J. (2011a). The Relationship between Organizational Capital and Firm Performance. In Proceedings of the 5th International Scientific Conference Finance and the Performance of Firms in Science, Education, and Practice. Zlín: Tomas Bata University in Zlín, 88-95.

8. Fiala, R. \& Borůvková, J. (2011b). Lineární regresní model jako nástroj měření organizačního kapitálu. Acta universitatis bohemiae meridionales: Vědecký časopis pro ekonomiku, ř́zeneni a obchod, 14 (1), 7-13.

9. Fiala, R. \& Borůvková, J. (2011c). The measurement of organizational capital. Littera scripta, 4 (2), 25-34.

10. Huselid, M. A. (1995). The Impact of Human Resource Management Practices on Turnover, Productivity, and corporate Financial Performance. Academy of Management Journal, 38 (3), 635-672. http://dx.doi.org/10.2307/256741

11. Ichniowski, C., Shaw, K. \& Prennushi, G. (1997). The Effects of Human Resource Management Practices on Productivity: A Study of Steel Finishing Lines. The American Economic Review, 87 (3), 291-313.

12. Ichniowski, C. \& Shaw, K. (1999). The Effects of Human Resource Management Systems on Economic Performance: An International Comparison of U.S. and Japanese Plants. Management Science, 45 (5), 704-721. http://dx.doi.org/10.1287/mnsc.45.5.704

13. Lev, B. \& Radhakrishnan, S. (2003). The Measurement of Firm-Specific Organization Capital. National Bureau of Economic Research Working Paper Series, 9581. Retrieved from http:// www.nber.org/papers/w9581.pdf

14. Lev, B. \& Radhakrishnan, S. (2004). The valuation of organization capital. Retrieved from http://citeseerx.ist.psu.edu/viewdoc/download?doi=10.1.1.196.8526\&rep=rep1\&type=pdf 
15. Ludewig, O. \& Sadowski, D. (2009). Measuring Organizational Capital. Schmalenbach Business Review, 61 (4), 393-412.

16. Miyagawa, T. \& Kim, Y. G. (2008). Measuring Organization Capital in Japan: An Empirical Assessment Using Firm-Level Data. Japan Center for Economic Research Discussion Paper, 112. Retrieved from: http://www.jcer.or.jp/eng/pdf/dp112f.pdf

17. Synek, M., et al. (2007). Manažerská ekonomika. Praha: Grada Publishing.

18. Youndt, M. A. \& Snell, S. A. (2004). Human Resource Configurations, Intellectual Capital, and Organizational Performance. Journal of Managerial Issues, 16, (3), 337-360

\section{Contact information}

Ing. Roman Fiala

College of Polytechnics Jiblava

Tolstébo 16, 58601 Jiblava, Cžech Republic

Tel: +420 567141223

E-mail:fiala@vspj.cz.

RNDr. Jana Boruivková, Ph.D.

College of Polytechnics Jiblava

Tolstébo 16, 58601 Jiblava, Cžech Republic

Tel: +420 567141184

E-mail:boruvkova@vspj.cr. 